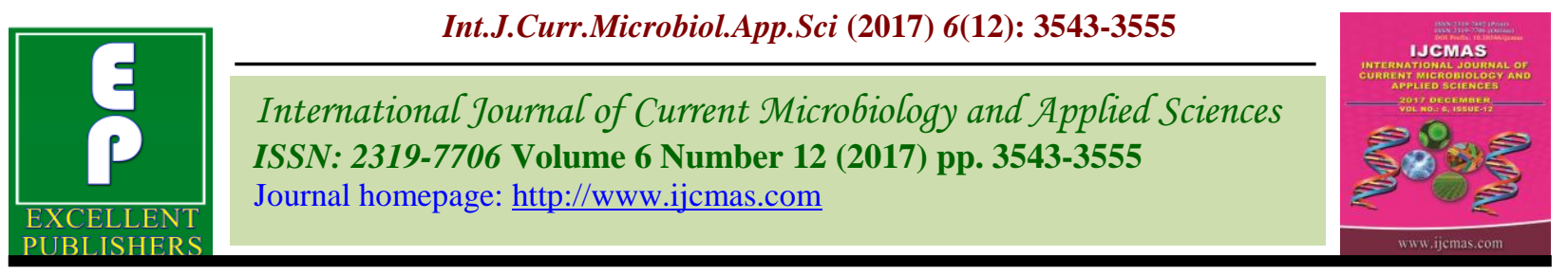

Original Research Article

https://doi.org/10.20546/ijcmas.2017.612.412

\title{
Management of Rice Weevil (Sitophilus oryzae L.) in Maize by Botanical Seed Treatments
}

\author{
A. Padmasri ${ }^{1^{*}}$, C. Srinivas ${ }^{2}$, K. Vijaya Lakshmi ${ }^{2}$, T. Pradeep ${ }^{2}$, \\ K. Rameash ${ }^{3}$, Ch. Anuradha ${ }^{2}$ and B. Anil ${ }^{2}$ \\ ${ }^{1}$ Seed Research and Technology Centre, PJTSAU, Rajendranagar, Hyderabad, Telangana, India \\ ${ }^{2}$ College of Agriculture, PJTSAU, Rajendranagar, Hyderabad, Telangana, India \\ ${ }^{3}$ Central Institute for Cotton Research, Regional Station, Coimbatore, Tamil Nadu, India \\ *Corresponding author
}

A B S T R A C T

Keywords

Management, Sitophilus oryzae, Mizae, Botanicals.

Article Info

Accepted:

26 October 2017

Available Online:

10 December 2017
An experiment was conducted at Seed Research and Technology Centre (SRTC), PJTSAU, Rajendranagar, Hyderabad during 2015-2016 to find out the effect of botanical seed treatments against Sitophilus oryzae in maize. The storage studies revealed that seeds treated with Acorus calamus rhizome powder @ $10 \mathrm{~g} \mathrm{~kg}^{-1}$ seed had recorded highest germination percentage (85.67), seedling vigour index (2354), less infestation (0.18 per cent) and weight loss ( 0.02 per cent $)$ at the end of nine months of storage.

\section{Introduction}

Maize (Zea mays. L) is one of most versatile emerging crop having wider adoptability under varied agro climatic conditions. Maize crop area and production may increase if seed is not constraint. The hybrids and varieties are reported to be highly susceptible to insect pest attacks both in the field and storage (Gimma et al., 2008). Hence, farmers are not as such beneficiaries of this increased production and productivity potential of new varieties and hybrids. More than 37 species of arthropod pests are associated with maize grain in storage (Abraham, 1991). Most of the maize grain harvested is stored on the farm, where post-harvest pest management practices are inadequate (Dubale, 2011) leading to huge amounts of maize seed losses due to pests of stored grain. Among the several insects attacking maize grain during storage rice weevil, Sitophilus spp (Linnaeus); Lesser grain borer, Rhizopertha domonica (Fabricius); Red flour beetle, Tribolium castaneum (Herbest); Rice moth Corcyra cepholonica (Stainton); Angumois grain moth, Sitotroga cereallela (oliver) are of economic importance. Sitophilus spp (Linn) is the most destructive insect pest of the stored raw cereal grains in the world (Champ and Dyte, 1976). Among Sitophilus zeamais (Motsch) and Sitophilus oryzae (L.), the 
former causes substantial losses to stored corn, amounting to 18.30 per cent (Adams, 1976) while a high damage of 92.40 to 98.30 per cent was reported by Bitran et al., (1978) in different parts of the world except India. On the other hand, S. oryzae causes enormous losses upto 100 per cent in stored maize in India and other countries (Irabagon, 1959, Singh et al., 1974). This evidently indicates the importance of $S$. oryzae in the storage of maize seed. The infestation starts in the field. The female weevil makes a small hole on the seed, deposits an egg and covers it with a gelatinous fluid. The apodus grub feeds inside the grain, pupates there itself and emerges through an hole made on the seed (Vasantharaj David and Kumaraswami, 1975) and damage is multiplied by several folds under storage.

Maize seeds are often traditionally stored in jute bags. This leads to significant increase of moisture during rainy seasons, thereby creating favourable conditions for grain weevil infestation (Hossain et al., 2007; Zunjare et al., 2014). Infested grain fetches lower market price due to reduced weight and nutritional value (Tefera, 2012). Seed viability of the damaged seed is drastically reduced and affects subsequent planting.

Insect pests can be managed with the use of synthetic insecticides but in storage, indiscriminate use of these synthetic insecticides resulted in the development of resistance (Subramanyam and Hagstrum 1995; Arthur, 1996) residues, undesirable effects on non-target organisms, human and environmental hazards (White and Leesch, 1995). Moreover, methyl bromide, one of the most effective fumigants in the control of stored pests, is banned from 2015 as per Montreal Protocol, due to its ozone depleting nature (Fields and White, 2002; Germinara et al., 2012). As a result, managing storage insects has become a challenge. In view of negative effects of synthetic insecticides, substances of plant origin for the control of stored grain insects are quite promising as they are more biodegradable, less toxic to human beings and safe to environment (Guzzo et al., 2006).

The use of plant products as seed protectants is a traditional method and is off great interest in the recent past. The plant materials are possessing insecticidal as well as repellent properties with little or no mammalian toxicity (Uma Reddy and shoba Reddy, 1978). Hence, a laboratory study was conducted to identify a plant product which proves to be superior to synthetic chemicals.

\section{Materials and Methods}

The experiment was carried out under ambient conditions at Seed Research and Technology centre (SRTC), Prof. Jayashankar Telangana State Agriculture University, Rajendranagar (PJTSAU), Hyderabad during 2015-2016. To assess the efficacy of botanicals as seed treatments one $\mathrm{kg}$ of freshly harvested certified seed (hybrid DHM 117) having very high percentage of germination and low moisture content $(<10$ per cent) was taken for each treatment.

Seeds were treated with botanicals viz., Lantana camera (Tantani) leaf powder @ 10 $\mathrm{g} \mathrm{kg}^{-1}$, Vitex negunda (Nirgudi leaf powder) @ $10 \mathrm{~g} \mathrm{~kg}^{-1}$, Acorus calamus (Sweet flag rhizome powder)@10 $\mathrm{g} \mathrm{kg}^{-1}$, Carica papaya (Papaya leaf powder) @ $10 \mathrm{~g} \mathrm{~kg} \mathrm{~kg}^{-1}$, Azadirachtina indica (Neem leaf powder) @ $10 \mathrm{~g} \mathrm{~kg}^{-1}$, Pongamia pinnata (Karanj oil)@ 5 $\mathrm{ml} \mathrm{kg}$ and compared with an insecticidal seed treatment, emamectin benzoate @ 40 mg $\mathrm{kg}^{-1}$ and untreated check. After treating the seeds with required concentration of each treatment, they were dried thoroughly in shade for one hour and transferred into the container. From the treated seeds, 100 gram 
were taken for each replication and they were transferred into glass jars and labeled as 3,6 and 9 months after treatment and 15 pairs of freshly emerged adults were released into each jar. The experiment was laid out in Completely Randomized Design (CRD) with three replications as suggested by Panse and Sukhatme (1978). The data were collected for every three months interval upto nine months on following parameters.

\section{Adult emergence}

Number of live and dead insects emerged out from 100 gram of each replication of the treatment was counted

\section{Percentage seed damage}

Percentage seed damage was calculated by taking a random sample of 100 seeds and counting the number of seeds with bored holes of $S$. oryzae and converted to percentage.

Percentage seed damage $=\frac{\text { Number of damaged seeds }}{\text { Total Number of seeds }} \times 100$

\section{Weight loss (\%) at different periods}

The count and weight method was used to determine seed weight loss using the formula:

$$
\mathrm{W}(\%)=\frac{(\mathrm{Wu} \times \mathrm{Nd})-(\mathrm{Wd} \times \mathrm{Nu})}{\mathrm{Wu} \times(\mathrm{Nd}+\mathrm{Nu})} \times 100
$$

Where, $\mathrm{W}$ is the weight loss $(\%), \mathrm{Wu}$ is the Weight of undamaged seed, $\mathrm{Nu}$ is the No. of undamaged seeds, $\mathrm{Wd}$ is the Weight of damaged seed and $\mathrm{Nd}$ is the No. of damaged seeds.

\section{Seed moisture content}

Moisture content of the seed was taken by using Dickyjohn moisture meter

\section{Seed germination percentage}

Germination of the seeds was tested by paper towel method by maintaining three replications of each treatment. 100 maize seeds were kept in moist paper towel and allowed to germinate in walk in germinator for 7 days and the percentage of germination was calculated by using the formula

Percentage of seed germination $=\frac{\text { Number of germinated seeds }}{\text { Total number of seeds }} \times 100$

\section{Seedling vigour index}

For determination of the maize seeds seedling vigour index, seven days old ten healthy germinated seedlings were selected from each replication of the treatment and shoot and root length of each of the ten seedlings were measured in centimeter and average length of the seedlings was calculated

Seedling length $=$ shoot length + root length

Seedling vigour index was calculated by multiplying germination percentage with seedling length as suggested by Abdul Baki and Anderson (1973)

Seedling vigour index $($ SVI $)=$ Per cent seed germination $\mathrm{x}$ seedling length

\section{Results and Discussions}

\section{Effect of botanical seed treatments on adult emergence of Sitophilus oryzae}

The data on mean number of adults emerged from the seeds treated with different botanicals are presented in Table 1 and Figure 1. The data on adult emergence of Sitophilus oryzae recorded at three months after treatment revealed that Acorus calamus rhyzome powder@10 g kg-1 seed, Pongamia pinnata oil @ $5 \mathrm{~g} \mathrm{~kg}^{-1}$ and emamectin 
benzoate 5 SG @ 40 mg kg ${ }^{1}$ seed gave complete protection to seed by preventing adult emergence. While, the adult emergence observed in Vitex negundo leaf powder @ 10 $\mathrm{g} \mathrm{kg}^{-1}$ (2.33). Significantly highest number of adult emergence was observed in untreated seeds (20.00).

Six months after treatment Acorus calamus rhyzome powder @ $10 \mathrm{~g} \mathrm{~kg}^{-1}$ seed and emamectin benzoate@ @ $40 \mathrm{mg} \mathrm{kg}^{-1}$ seed were equally effective and completely prevented the adult emergence. Pongamia pinnata oil @ $5 \mathrm{~g} \mathrm{~kg}^{-1}$ was effective upto three months of treatment but failed to prevent after six and nine months after treatment and resulted 2.00 and 6.00 adults respectively.

After nine months of treatment imposition emamectin benzoate $40 \mathrm{mg} \mathrm{kg}^{-1}$ prevented the adult emergence in treated seeds while only one adult from Acorus calamus rhyzome powder@10 $\mathrm{g} \mathrm{kg}^{-1}$ seed was recorded. In the rest of the treatments the adult emergence varied from 4.67 to 83.00 as against 98.33 adults in control.

The results obtained from adult emergence studies clearly revealed superior performance of Acorus calamus rhyzome powder @10 g $\mathrm{kg}^{-1}$ seed in protecting maize seed for six months and was on par with emamectin benzoate@ $90 \mathrm{mg} \mathrm{kg}^{-1}$ seed. The few eggs laid on Acorus calamus rhyzome powder @ 10 $\mathrm{g} \mathrm{kg}$ seeds, could not complete their development resulting in no adult emergence upto six months. The reduction in adult emergence that was recorded could also be due to low hatchability of eggs.

The results were in agreement the findings of Shukla et al., (2009) concluded that the dose of $5 \mathrm{mg}$ rhizome powder of Acorus calamus per gram proved fatal, causing 100 per cent mortality of $C$. chinensis in chickpea and completely inhibiting $\mathrm{F}_{1}$ emergence.

\section{Effect of botanical seed treatments on seed} damage by $S$. oryzae

The results obtained from the effect of botanicals on per cent seed damage by Sitophilus oryzae are presented in Table 1 and Figure 2.

The efficacy of botanicals on seed damage by Sitophilus oryzae indicate superior performance of emamectin benzoate 5 SG @ $40 \mathrm{mg} \mathrm{kg}^{-1}$, Acorus calamus rhyzome powder @ $10 \mathrm{~g} \mathrm{~kg}^{-1}$ and Pongamia pinnata oil @ $5 \mathrm{ml}$ $\mathrm{kg}^{-1}$ over the rest of the treatments as, they completely protect the seed from damage by Sitophilus oryzae upto three months of treatment, followed by Vitex negundo leaf powder@10 $\mathrm{g} \mathrm{kg}^{-1}$ also gave good control of Sitophilus oryzae and resulted in 0.26 per cent seed damage. In the rest of the treatments seed damage varied from 1.49 to 2.66 per cent as against 7.42 per cent seed damage in the control.

After six months of treatment also Acorus calamus rhyzome powder @ $10 \mathrm{~g} \mathrm{~kg}^{-1}$ continued its supremacy over other botanicals and completely protected the seed from damage by $S$. oryzae and on par with chemical treatment emamectin benzoate $5 \mathrm{SG}$ @ $40 \mathrm{mg} \mathrm{kg}^{-1}$ followed by Pongamia pinnata oil @ $5 \mathrm{ml} \mathrm{kg}^{-1}$ (1.04 per cent). In the rest of the treatments seed damage varied from 2.14 to 3.53 per cent as against 12.12 per cent seed damage in the untreated control.

After nine months of treatment similar trend was observed. Emamectin benzoate 5 SG @ $40 \mathrm{mg} \mathrm{kg}{ }^{-1}$ treated seeds gave complete protection and was on par with Acorus calamus rhyzome powder @ $10 \mathrm{~g} \mathrm{~kg}^{-1}$ treated seeds ( 0.18 per cent) followed by Pongamia pinnata oil @ $5 \mathrm{ml} \mathrm{kg}^{-1}$ treated seeds (2.22 per cent). In the rest of the treatments per cent seed infestation varied from 3.57 to 18.57 per cent as against untreated control (24.18 per 
cent). The present findings are supported by the findings of Sunil Kumar (2003) who reported that the sweet flag rhizome powder alone at one per cent afforded maximum protection to the seeds up to 60 DAS. Later the damage increased to 17.83 at the end of the year. However, present findings are in agreement with Hampanna (2004) who reported that the sweet flag rhizome powder at two per cent afforded complete protection to chickpea as there was no seed damage. In the present study there was least seed damage to seeds even after 180 days. This study is supported by Umareddy and Shobhareddy (1987) who did not notice the boring of seeds by $C$. chinesis treated with sweet flag at four and two per cent concentration to green gram seeds.

Similar work was done by Jadhav (2006) who reported that, no seed damage was reported at 180 days after treatment when treated with $A$. calamus rhizome powder @ 1 per cent while custard apple seed powder, neem seed powder @ 5 per cent and malathion 5 D @ 5 per cent recorded significantly less percentage of damaged seeds. Kudachi (2008) who reported that, seeds treated with A. calamus rhizome powder @ 1 per cent was significantly superior with no damage to seeds. While, significantly maximum damage to seeds was noticed in untreated check (82.00 per cent).

Effect of botanical seed treatments on weight loss of maize seeds caused by $S$. oryzae

The data recorded on weight loss due to the infestation of maize seeds by Sitophilus oryzae are presented in the Table 1 and Figure 3.

A perusal of data on the per cent weight loss per cent due to infestation by Sitophilus oryzae after three months after treatment revealed that no weight loss was observed in the seeds treated with emamectin benzoate @ $40 \mathrm{mg} \mathrm{kg}^{-1}$, Acorus calamus rhyzome powder @10 $\mathrm{g} \mathrm{kg}^{-1}$ and Pongamia pinnata oil @ $5 \mathrm{ml}$ $\mathrm{kg}^{-1}$ seed. In the rest of the treatments weight loss per cent ranged from 0.51 to 0.86 per cent while the highest weight loss of 2.30 per cent was recorded in the untreated control.

After six months no weight loss was observed in emamectin benzoate @ $40 \mathrm{mg} \mathrm{kg}^{-1}$ and Acorus calamus rhyzome powder @ $10 \mathrm{~g} \mathrm{~kg}^{-1}$ followed by Pongamia pinnata oil $5 \mathrm{ml} \mathrm{kg}{ }^{-1}$ seed $(0.04 \%)$.

In the remaining treatments the weight loss ranged from 0.64 to 2.34 per cent. However, the highest per cent weight loss was recorded in untreated control (4.79 per cent).

Emamectin benzoate@40 mg kg ${ }^{-1}$ gave complete protection against Sitophilus oryzae (L.) even after 9 months after treatment. The per cent weight loss of 0.02 per cent and 0.56 per cent was recorded in Acorus calamus rhyzome powder@10 g kg $\mathrm{g}^{-1}$ and Pongamia pinnata oil $5 \mathrm{ml} \mathrm{kg}^{-1}$ seeds respectively. Both were on par with each other.

In the remaining treatments the weight loss ranged from 1.67 to 4.17 per cent. However, the highest per cent weight loss was recorded in untreated control (6.63 per cent) and was significantly inferior to the rest of the treatments.

These findings are in corroboration with the findings of Paneru et al., (1993), Jilani and Saxena (1984), Khan and Borle (1985), who reported that A. calamus as a good protectant with long residual activity on mung which was also confirmed by Biradar (2000) and Sunil Kumar (2003). These findings are also supported by Kalasagonda (1998) who reported no weight loss in wheat grains at 0.8 per cent concentration of sweet flag rhizome powder. 
Table.1 Effect of botanicals on adult emergence, of Sitophilus oryzae, seed damage and weight loss of maize seed

\begin{tabular}{|c|c|c|c|c|c|c|c|c|c|c|}
\hline \multirow{2}{*}{ Treatments } & \multirow{2}{*}{$\begin{array}{c}\text { Dosage } \\
\mathrm{Kg}^{-1} \\
\text { seed }\end{array}$} & \multicolumn{3}{|c|}{$\begin{array}{c}\text { Number of adult emergence } \\
\text { Storage duration }\end{array}$} & \multicolumn{3}{|c|}{$\begin{array}{l}\text { Seed damage }(\%) \\
\text { Storage duration }\end{array}$} & \multicolumn{3}{|c|}{$\begin{array}{c}\text { Weight loss }(\%) \\
\text { Storage duration }\end{array}$} \\
\hline & & 3 MAST & 6 MAST & 9 MAST & 3 MAST & & 9 MAST & 3 MAST & 6 MAST & 9 MAST \\
\hline $\begin{array}{l}\mathrm{T}_{1} \text {-Lantana camera } \\
\text { (Tantani) leaf powder }\end{array}$ & $10 \mathrm{~g}$ & $\begin{array}{l}15.00 \\
(3.94)\end{array}$ & $\begin{array}{l}46.33 \\
(6.84)\end{array}$ & $\begin{array}{l}83.00 \\
(9.14)\end{array}$ & $\begin{array}{c}2.66 \\
(3.39)\end{array}$ & $\begin{array}{c}3.53 \\
(10.83)\end{array}$ & $\begin{array}{c}18.57 \\
(25.52)\end{array}$ & $\begin{array}{l}00.86 \\
(5.31)\end{array}$ & $\begin{array}{c}2.34 \\
(8.80)\end{array}$ & $\begin{array}{c}4.71 \\
(12.54)\end{array}$ \\
\hline $\begin{array}{l}\mathrm{T}_{2} \text {-Vitex negundo } \\
\text { (Nirgudi) leaf powder }\end{array}$ & $10 \mathrm{~g}$ & $\begin{array}{c}2.33 \\
(1.66)\end{array}$ & $\begin{array}{c}3.67 \\
(2.04)\end{array}$ & $\begin{array}{l}4.67 \\
(2.27)\end{array}$ & $\begin{array}{l}00.26 \\
(4.06)\end{array}$ & $\begin{array}{c}2.14 \\
(8.41)\end{array}$ & $\begin{array}{c}3.57 \\
(10.88)\end{array}$ & $\begin{array}{l}00.51 \\
(4.59)\end{array}$ & $\begin{array}{l}00.64 \\
(4.57)\end{array}$ & $\begin{array}{l}1.67 \\
(7.42)\end{array}$ \\
\hline $\begin{array}{l}\mathrm{T}_{3} \text {-Acorus calamus (Sweet } \\
\text { flag), rhyzome powder }\end{array}$ & $10 \mathrm{~g}$ & $\begin{array}{c}0.00 \\
(0.71)\end{array}$ & $\begin{array}{c}0.00 \\
(0.71)\end{array}$ & $\begin{array}{l}1.00 \\
(1.23)\end{array}$ & $\begin{array}{l}00.00 \\
(4.06)\end{array}$ & $\begin{array}{l}00.00 \\
(4.06)\end{array}$ & $\begin{array}{c}0.18 \\
(4.10)\end{array}$ & $\begin{array}{l}00.00 \\
(4.06)\end{array}$ & $\begin{array}{l}00.00 \\
(4.06)\end{array}$ & $\begin{array}{c}0.02 \\
(4.05)\end{array}$ \\
\hline $\begin{array}{l}\mathrm{T}_{4-} \text { Carica papaya } \\
\text { (Papaya) leaf powder }\end{array}$ & $10 \mathrm{~g}$ & $\begin{array}{c}6.00 \\
(2.54)\end{array}$ & $\begin{array}{c}6.67 \\
(2.68)\end{array}$ & $\begin{array}{c}8.33 \\
(2.97)\end{array}$ & $\begin{array}{c}1.49 \\
(7.01)\end{array}$ & $\begin{array}{c}3.21 \\
(10.32)\end{array}$ & $\begin{array}{c}4.31 \\
(11.99)\end{array}$ & $\begin{array}{l}00.73 \\
(4.89)\end{array}$ & $\begin{array}{l}00.85 \\
(5.28)\end{array}$ & $\begin{array}{c}2.00 \\
(8.11)\end{array}$ \\
\hline $\begin{array}{l}\mathrm{T}_{5} \text {-Azadirachtina indica } \\
\text { (Neem) leaf powder }\end{array}$ & $10 \mathrm{~g}$ & $\begin{array}{l}10.00 \\
(3.24)\end{array}$ & $\begin{array}{l}26.00 \\
(5.15)\end{array}$ & $\begin{array}{l}41.67 \\
(6.49)\end{array}$ & $\begin{array}{c}2.56 \\
(9.21)\end{array}$ & $\begin{array}{c}3.12 \\
(10.18)\end{array}$ & $\begin{array}{c}4.56 \\
(12.33)\end{array}$ & $\begin{array}{l}00.78 \\
(5.08)\end{array}$ & $\begin{array}{c}1.23 \\
(6.38)\end{array}$ & $\begin{array}{c}2.81 \\
(9.65)\end{array}$ \\
\hline $\mathrm{T}_{6}$-Emamectin benzoate & $40 \mathrm{mg}$ & $\begin{array}{c}0.00 \\
(0.71)\end{array}$ & $\begin{array}{c}0.00 \\
(0.71)\end{array}$ & $\begin{array}{c}0.00 \\
(0.71)\end{array}$ & $\begin{array}{l}00.00 \\
(4.06)\end{array}$ & $\begin{array}{l}00.00 \\
(4.06)\end{array}$ & $\begin{array}{l}00.00 \\
(4.06)\end{array}$ & $\begin{array}{l}00.00 \\
(4.06)\end{array}$ & $\begin{array}{l}00.00 \\
(4.06)\end{array}$ & $\begin{array}{l}00.00 \\
(4.06)\end{array}$ \\
\hline $\begin{array}{l}\mathrm{T}_{7} \text {-Pongamia pinnata } \\
\text { (Karanj) oil }\end{array}$ & $5 \mathrm{ml}$ & $\begin{array}{c}0.00 \\
(0.71)\end{array}$ & $\begin{array}{c}2.00 \\
(1.56)\end{array}$ & $\begin{array}{c}6.00 \\
(2.52)\end{array}$ & $\begin{array}{l}00.00 \\
(4.06)\end{array}$ & $\begin{array}{c}1.04 \\
(5.86)\end{array}$ & $\begin{array}{c}2.23 \\
(8.59)\end{array}$ & $\begin{array}{l}00.00 \\
(4.06)\end{array}$ & $\begin{array}{l}00.04 \\
(4.06)\end{array}$ & $\begin{array}{l}00.56 \\
(4.30)\end{array}$ \\
\hline $\mathrm{T}_{8}$-Untreated control & & $\begin{array}{l}20.00 \\
(4.64)\end{array}$ & $\begin{array}{l}51.67 \\
(7.22)\end{array}$ & $\begin{array}{l}98.33 \\
(9.94)\end{array}$ & $\begin{array}{c}7.42 \\
(15.81)\end{array}$ & $\begin{array}{c}12.12 \\
(20.37)\end{array}$ & $\begin{array}{c}24.18 \\
(29.45)\end{array}$ & $\begin{array}{c}2.30 \\
(8.72)\end{array}$ & $\begin{array}{c}4.79 \\
(12.64)\end{array}$ & $\begin{array}{c}6.63 \\
(14.92)\end{array}$ \\
\hline SEm \pm & & 0.10 & 0.10 & 0.11 & 0.06 & 0.09 & 0.17 & 0.20 & 0.11 & 0.21 \\
\hline $\mathrm{CD}(\mathrm{P}=0.05)$ & & 0.29 & 0.29 & 0.34 & 0.18 & 0.26 & 0.5 & 0.60 & 0.33 & 0.62 \\
\hline $\mathrm{CV}(\%)$ & & 7.47 & 5.04 & 4.41 & 1.42 & 1.62 & 2.14 & 6.86 & 3.07 & 4.42 \\
\hline
\end{tabular}


Table.2 Effect of botanicals on Germination, seedling vigour index and moisture content of maize seed

\begin{tabular}{|c|c|c|c|c|c|c|c|c|c|c|}
\hline \multirow{3}{*}{ Treatments } & \multirow{3}{*}{$\begin{array}{l}\text { Dosag } \\
\text { e kg } \\
\text { seed }\end{array}$} & \multicolumn{3}{|c|}{ Germination percentage } & \multicolumn{3}{|c|}{ Seedling Vigour Index } & \multicolumn{3}{|c|}{ Moisture (\%) } \\
\hline & & \multicolumn{3}{|c|}{ Storage duration } & \multicolumn{3}{|c|}{ Storage duration } & \multicolumn{3}{|c|}{ Storage duration } \\
\hline & & 3 MAST & 6 MAST & 9 MAST & 3 MAST & 6 MAST & 9MAST & 3 MAST & 6MAST & 9MAST \\
\hline $\begin{array}{l}\mathrm{T}_{1}-\text { Lantana camera } \\
\text { (Tantani) leaf powder }\end{array}$ & $10 \mathrm{~g}$ & $\begin{array}{c}93.33 \\
(75.05)\end{array}$ & $\begin{array}{c}89.33 \\
(70.96)\end{array}$ & $\begin{array}{c}66.67 \\
(54.74)\end{array}$ & 3461 & 3019 & 1758 & $\begin{array}{c}6.73 \\
(15.03)\end{array}$ & $\begin{array}{c}8.23 \\
(16.67)\end{array}$ & $\begin{array}{c}10.13 \\
(18.56)\end{array}$ \\
\hline $\begin{array}{l}\mathrm{T}_{2}-\text { Vitex } \\
\text { negundo(Nirgudi) leaf } \\
\text { powder }\end{array}$ & $10 \mathrm{~g}$ & $\begin{array}{c}96.00 \\
(79.33)\end{array}$ & $\begin{array}{c}91.33 \\
(72.88)\end{array}$ & $\begin{array}{c}84.00 \\
(66.43)\end{array}$ & 3501 & 3010 & 2046 & $\begin{array}{c}7.1 \\
(15.45)\end{array}$ & $\begin{array}{c}8.03 \\
(16.46)\end{array}$ & $\begin{array}{c}9.16 \\
(17.62)\end{array}$ \\
\hline $\begin{array}{l}\mathrm{T}_{3} \text {-Acorus calamus } \\
\text { (Sweet flag), rhyzome } \\
\text { powder }\end{array}$ & $10 \mathrm{~g}$ & $\begin{array}{c}97.3 \\
(80.96)\end{array}$ & $\begin{array}{c}92.33 \\
(74.05)\end{array}$ & $\begin{array}{c}85.67 \\
(67.76)\end{array}$ & 3690 & 3410 & 2354 & $\begin{array}{c}6.86 \\
(15.18)\end{array}$ & $\begin{array}{c}8.4 \\
(16.85)\end{array}$ & $\begin{array}{c}9.36 \\
(17.82)\end{array}$ \\
\hline $\begin{array}{l}\mathrm{T}_{4}-\text { Carica papaya } \\
\text { (Papaya) leaf powder }\end{array}$ & $10 \mathrm{~g}$ & $\begin{array}{c}93.67 \\
(75.43)\end{array}$ & $\begin{array}{c}91.67 \\
(73.34)\end{array}$ & $\begin{array}{c}75.67 \\
(60.51)\end{array}$ & 3464 & 3009 & 2236 & $\begin{array}{c}6.86 \\
(15.18)\end{array}$ & $\begin{array}{c}7.77 \\
(16.18)\end{array}$ & $\begin{array}{c}10.16 \\
(18.59)\end{array}$ \\
\hline $\begin{array}{l}\mathrm{T}_{5}-\text { Azadirachtina indica } \\
(\mathrm{Neem}) \text { leaf powder }\end{array}$ & $10 \mathrm{~g}$ & $\begin{array}{c}96.33 \\
(79.14)\end{array}$ & $\begin{array}{c}90.33 \\
(71.92)\end{array}$ & $\begin{array}{c}74.33 \\
(59.60)\end{array}$ & 3271 & 3041 & 2049 & $\begin{array}{c}6.9 \\
(15.23)\end{array}$ & $\begin{array}{c}7.93 \\
(16.36)\end{array}$ & $\begin{array}{c}10.03 \\
(18.47)\end{array}$ \\
\hline $\mathrm{T}_{6}-$ Emamectin benzoate & $40 \mathrm{mg}$ & $\begin{array}{c}97.67 \\
(81.48)\end{array}$ & $\begin{array}{c}90.00 \\
(71.57)\end{array}$ & $\begin{array}{c}89.00 \\
(70.64)\end{array}$ & 3654 & 3367 & 2358 & $\begin{array}{c}8.00 \\
(16.39)\end{array}$ & $\begin{array}{c}8.43 \\
(16.88)\end{array}$ & $\begin{array}{c}10.7 \\
(19.09)\end{array}$ \\
\hline $\begin{array}{l}\mathrm{T}_{7}-\text { Pongamia pinnata } \\
\text { (Karanj) oil }\end{array}$ & $5 \mathrm{ml}$ & $\begin{array}{c}93.3 \\
(75.2)\end{array}$ & $\begin{array}{c}89.67 \\
(71.25)\end{array}$ & $\begin{array}{c}77.33 \\
(61.58)\end{array}$ & 3162 & 3013 & 1870 & $\begin{array}{c}6.63 \\
(14.92)\end{array}$ & $\begin{array}{c}8.53 \\
(16.98)\end{array}$ & $\begin{array}{c}10.36 \\
(18.78)\end{array}$ \\
\hline $\mathrm{T}_{8}$ - Untreated control & & $\begin{array}{c}90.67 \\
(72.23)\end{array}$ & $\begin{array}{c}87.33 \\
(69.15)\end{array}$ & $\begin{array}{c}47.67 \\
(43.66)\end{array}$ & 3162 & 2768 & 1596 & $\begin{array}{c}8.83 \\
(17.28)\end{array}$ & $\begin{array}{c}8.87 \\
(17.32)\end{array}$ & $\begin{array}{c}10.60 \\
(19.00)\end{array}$ \\
\hline SEm \pm & & 1.92 & 0.84 & 1.11 & 59 & 70 & 22 & 0.43 & 0.07 & 0.14 \\
\hline $\mathrm{CD}(\mathrm{P}=0.05)$ & & 5.79 & 2.53 & 3.33 & 178 & 209 & 65 & 1.29 & 0.20 & 0.43 \\
\hline $\mathrm{CV}(\%)$ & & 4.32 & 2.03 & 3.17 & 3.00 & 4.00 & 2.00 & 4.69 & 0.70 & 1.35 \\
\hline
\end{tabular}




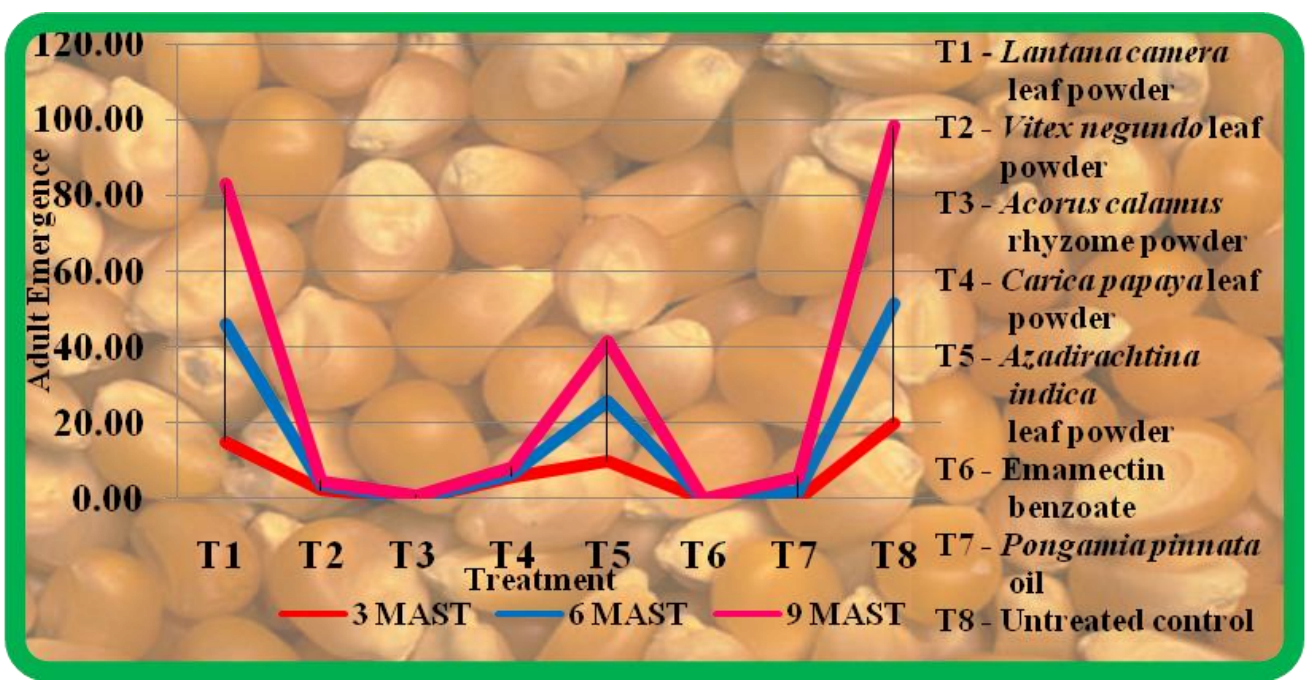

Fig.1 Effect of botanicals on adult emergence of Sitophilus oryzae

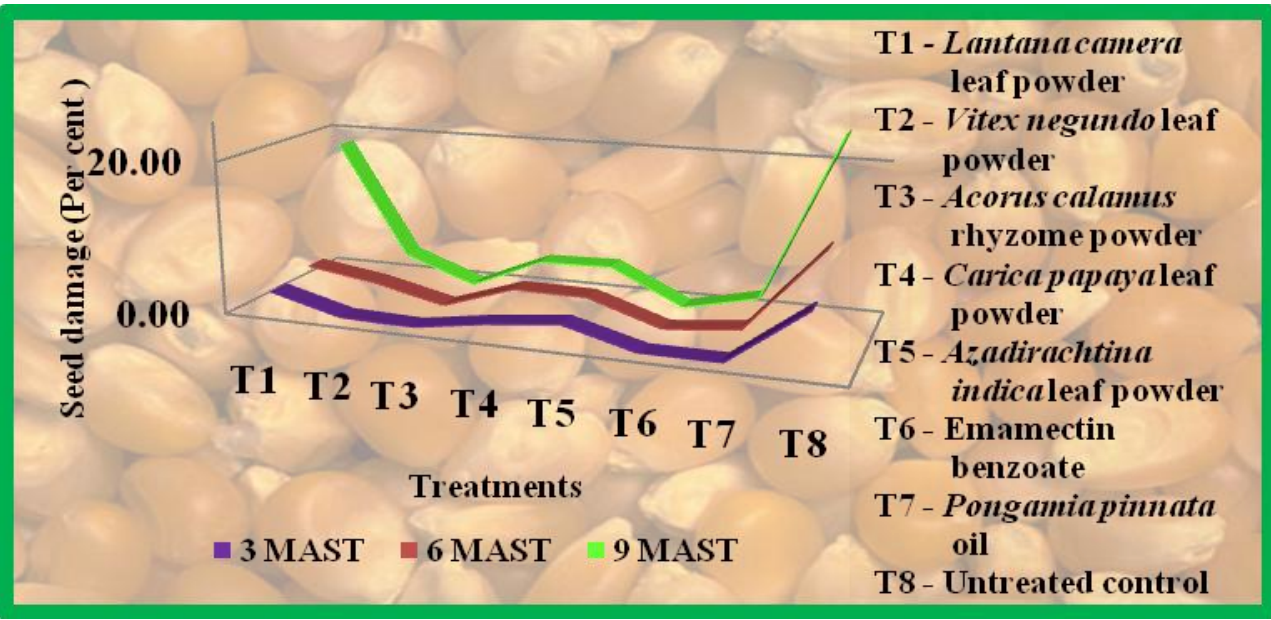

Fig.2 Effect of botanicals on seed damage caused by Sitophilus oryzae

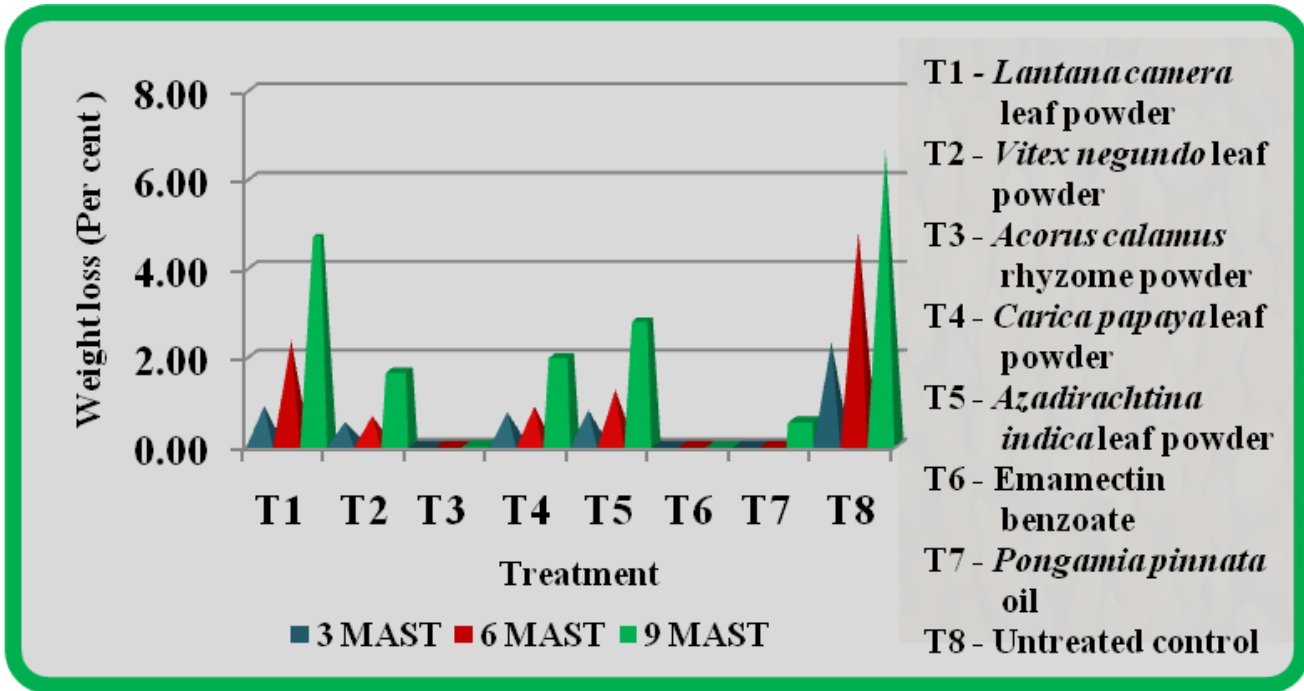

Fig.3 Effect of botanicals on weight loss caused by Sitophilus oryzae 
Effect of botanical seed treatments on germination of maize seeds

The results obtained on effect of botanicals on germination of maize seed were presented in the Table 2 .

Highest germination percentage was observed in emamectin benzoate $5 \mathrm{SG}$ @ $40 \mathrm{mg} \mathrm{kg}^{-1}$ treated seeds ( 97.67 per cent), which was on par with all other botanical seed treatments. There was no significant difference among botanical treatments and emamectin benzoate $5 \mathrm{SG} @ 40 \mathrm{mg} \mathrm{kg}^{-1}$. The least germination percentage was observed in control (90.67). After six months of storage highest germination percentage was recorded in Acorus calamus rhyzome powder @ $10 \mathrm{~g} \mathrm{~kg}^{-}$ ${ }^{1}$ (92.33) was on par with Vitex negundo leaf powder@10 g kg-1 (91.33), Carica papaya leaf powder @ $10 \mathrm{~g} \mathrm{~kg}^{-1}$ (91.67), Azadirachtina indica leaf powder @ $10 \mathrm{~g} \mathrm{~kg}^{-1}$ (90.33) and emamectin benzoate 5 SG @ 40 $\mathrm{mg} \mathrm{kg}^{-1}(90.00)$. While lowest germination percentage was observed in control 87.33 on par with Lantana camera leaf powder (89.33) and Pongamia pinnata (89.67).

Nine months after treatment imposition highest germination percentage was recorded in emamectin benzoate 5 SG (89.00) was on par with Acorus calamus rhyzome powder treated seeds (85.67) followed by Vitex negundo leaf powder (84.00). The lowest germination was observed in untreated control (47.67).

While germination percentage in Pongamia pinnata treated seeds were $93.3,89.67$ and 77.33 per cent as compared with control $90.67,87.33$ and 47.67 per cent, respectively at three, six and nine months after treatment.

The perusal of the data obtained on the effect of seed protectant on germination of maize seeds suggested that there was no negative effect of botanical seed treatments on the germination of maize seeds.

Effect of botanical seed treatments on seedling vigour index of maize seeds

The data obtained from the effect of botanical seed treatments on seedling vigour index of maize seed are presented in Table 2. After three months of treatment the highest seedling vigour index was observed in Acorus calamus rhyzome powder@10 g kg-1(3690)was on par with emamectin benzoate 5 SG @ 40 mg $\mathrm{kg}^{-1}(3654)$. The lowest seedling vigour index was observed in Pogamia pinnata oil @ 5 ml $\mathrm{kg}^{-1}$ and untreated control (3162).

The data recorded after six months of treatment revealed that Acorus calamus rhyzome powder@10 g kg-1 (3410) and emamectin benzoate@40mg kg-1 (3367) were superior over other treatments followed by Azadirachtina indica leaf powder @ 10g $\mathrm{kg}^{-1}$ (3041) was on par with Lantana camera leaf powder @10 $\mathrm{g} \mathrm{kg}^{-1}(3019)$, Carica papaya leaf powder@10 $\mathrm{kg}^{-1}(3009)$ and Pongamia pinnata oil @ $5 \mathrm{ml} \mathrm{kg}^{-1}$ (3013). The significantly lowest vigour was recorded in untreated control (2768).

The observations recorded after nine months of treatment also showed similar trend as highest seedling vigour index observed in emamectin benzoate 5 SG @ 40 mg $\mathrm{kg}^{1}(2358)$ and Acorus calamus @ $10 \mathrm{~g} \mathrm{~kg}^{-1}$ (2354) which were on par with each other. In the rest of the treatments, seedling vigour index varied between 2236 and 1758 while lowest seedling vigour index was recorded in untreated control (1596).

These findings are in accordance with the findings of the earlier worker.

Gupta et al., (1992) reported that Pongamia pinnata did not affect the viability of wheat 
seeds. Mahalakshmi (2010) reported that Pongamia pinnata had no advers effect on germination of pigeonpea. Sandeep et al., (2013) reported that seeds treated with sweet flag rhizomes powder@10 g kg-1 seed had recorded higher germination (87.3), vigour index (2864) and less infestation (3.6 per cent) at the end of 10 months of storage of sweet corn seed.

Rajesh et al., (2017) observed sorghum seeds treated with sweet flag powder (2.5 per cent) and custard apple seed powder 2.5 per cent showed significantly higher 100 seed weight, germination percentage, seedling vigour, field emergence percentage and adult mortality as compared to other seed treatment and control during storage

Seeds treated with different botanicals did not affect the viability of seeds when compared with control. Overall results indicate that botanicals used in the present investigation had no adverse effect on seed viability of maize seed and can be safely used for treating the seed.

\section{Effect of botanical seed treatments on moisture content of maize seed}

The moisture content of maize seeds treated with botanicals showed significant variation among the treatments (Table 2).

The observations recorded at three months after treatment imposition revealed that lowest moisture content was recorded in Pongamia pinnata oil @ $5 \mathrm{ml} \mathrm{kg}^{-1}$ (6.63 per cent) which was on par with rest of the botanical treatments Lantana camera leaf powder@10g kg ${ }^{1}$ (6.73 per cent), Vitex negundo leaf powder @ $10 \mathrm{~g} \mathrm{~kg}^{-1}$ (7.1 per cent), Acorus calamus rhyzome powder @ $10 \mathrm{~g} \mathrm{~kg}^{-1}$ (6.86 per cent), Carica papaya leaf

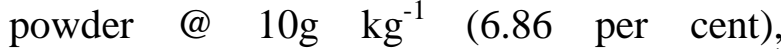
Azadiractina indica leaf powder @ $10 \mathrm{~g} \mathrm{~kg}^{-1}$
(6.9 per cent) followed by emamectin benzoate5 SG @ 40 mg kg-1 (8.00 per cent) was on par with untreated control (8.83 per cent).

The observations recorded at six months after treatment imposition revealed that lowest moisture content was recorded in Carica papaya leaf powder@10 $\mathrm{g} \mathrm{kg}^{-1}$ seeds (7.73 per cent) which was on par with Azadiractina indica leaf powder@10 $\mathrm{g} \mathrm{kg}^{-1}$ (7.93 per cent), followed by Vitex negudo leaf powder @ 10g $\mathrm{kg}^{-1}$ (8.03 per cent) and Lantarna camera leaf powder@10 $@ \mathrm{~kg}^{-1}$ (8.23 per cent) treated seeds. The moisture content of maize seeds in the rest of the treatments varied from (8.4 to 8.87 per cent).

The observations recorded at nine months after treatment imposition revealed that lowest moisture content was recorded in Vitex negundo leaf powder @ $10 \mathrm{~g} \mathrm{~kg}^{-1}$ seeds were (9.16 per cent) and was on par with Acorus calamus rhyzome powder @ $10 \mathrm{~g} \mathrm{~kg}^{-1}$ (9.36 per cent) followed by Azadiractina indica leaf powder@10 $\mathrm{g} \mathrm{kg}^{-1}$ (10.03 per cent) was on par with Pongamia pinnata oil @ $5 \mathrm{ml} \mathrm{kg}^{-1}$ (10.36 per cent) Lantana camera leaf powder @ $10 \mathrm{~g} \mathrm{~kg}^{-1}$ (10.13 per cent), Carica papaya leaf powder @ $10 \mathrm{~g} \mathrm{~kg}^{-1}$ (10.16 per cent), where as in untreated seeds moisture content observed was (10.60 per cent) and emamectin benzoate 5 SG @ $40 \mathrm{mg} \mathrm{kg}^{-1}$ seeds (10.70 per cent) and were on par with each other.

Among botanical seed treatments Acorus calamus was able to maintain germination above IMSCS and gave complete protection to seed by preventing seed damage due to Sitophilus oryzae.

Insecticidal activity of A. calamus is well documented against a range of insect pests (El-Nahal et al., 1989; Schmidt and Streloke, 1994; Lee et al., 2002). The present study recommends the use of rhizomes of Acorus 
calamus for the control of weevils. Products derived from $A$. calamus are used as pharmaceuticals worldwide and could therefore be considered less harmful to humans than most conventional insecticides.

\section{References}

Abdul-Baki, A.A and Anderson, J.D. 1973. Vigour determination in soybean seeds by multiple criteria. Crop Science. 13: 630-633.

Abraham, T. 1991. The biology, significance and control of the maize weevil, Sitophilus zeamais Motsch. (Coleoptera: Curculionidae) on stored maize, M.Sc., Thesis, Alemaya University of Agriculture, Alemaya, Ethiopia.

Adams, J. M., 1976. Weight loss caused by development of $S$. oryzae. Journal of Stored Production Research, 12: 269272.

Arthur FH (1996) Grain protectants: current status and prospects for the future. $J$ Stored Prod Res 32: 293-302. J Food Sci Technol., (May 2016) 53(5): 2169 2184

Biradar, B. S., 2000, Prevention of cross infestation by Sitophilus oryzae Linn. and Rhizopertha dominica Fab. in stored wheat. M.Sc.(Agri.) Thesis, Uni, of Agric. Sci., Dharwad (India), 120pp.

Bitran, E. A., Campos, T. B. and Oliveira, D. A. 1978. Experimental evaluation of damage caused by pests in stored maize under confined conditions. Sitophilus zeamais (Coleoptera: Curculionidae). Biological Science.45: 223-227.

Champ, B. R. and Dyte, C. E., 1976. Global survey of pesticide susceptibility of stored grain pests. FAO Plant Protection Science, No. 5, FAO, Rome.

Dubale, B. 2011. Management Practices and Quality of Maize Stored in Traditional Storage Containers: Gombisa and Sacks in Selected Districts Of Jimma, MSc.
Thesis, Aromaya Univ. Agric. Aromaya, Ethiopia.

El-Nahal, A. K. M., Schmidt, G. H. and Risha, E. M. 1989. Vapours of Acorus calamus oil-a space treatment for stored-product insects. J. Stored Prod. Res. 25: 211-216.

Fields PG, White NDG (2002) Alternatives to methyl bromide treatments for storedproduct insect and quarantine insect. Ann Rev Ent 47: 331-359.

Germinara, G. De Cristofaro, A., Rotundo, G. 2012. Bioactivity of shortchain aliphatic ketones against adults of the granary weevil, Sitophilus granarius (L.). Pest Manag Sci 68:371-377.

Gimma, D., Tadele, T. and Abraham, T. 2008. Importance of husk covering on field infestation of maize by Sitophilus zeamais Motsch (Coleoptera: Curculionidea) at Bako, Western Ethiopia, AJB 7(20): 3777-3782.

Gupta, A.K., Behat S.R., Awasthi, B.K. and Varma, R.A. 1990. Screening of some maize genotypes against Sitophilus oryzae. Indian Journal of Entomology. 61: 265-268.

Guzzo EC, Tavares MAGC, Vendramim JD (2006) Evaluation of insecticidal activity of aqueous extracts of Chenopodium spp. in relation to Rhyzopertha dominica (Fabr.) (Coleoptera: Bostrichidae), pp. 926930. In: Proceedings of the 9th International Working Conference on Stored-Product Protection, 15-18 October 2006, Campinas, Sao Paulo, Brazil. Brazilian Post-harvest Association-ABRAPOS, Passo Fundo

Hampanna, 2004, Survey and evaluation of indigenous inert materials against major store insect pests of cereals and pulses. M.Sc. (Agri.) Thesis, Uni. of Agric. Sci., Dharwad (India), 145pp.

Hossain, F., Boddupalli, P. M., Sharma, R. K., Kumar, P., and Singh, B. B. 2007. 
Evaluation of quality protein maize genotypes for resistance to stored grain weevil Sitophilus oryzae (Coleoptera: Curculionidae). International Journal of Tropical Insect Science, 27: 114-121

Irabgon, T. A. 1959. Rice weevil damage to stored corn. Journal of economic Entomology 52: 1130-1136.

Jadhav, K., 2006, Biology and management of Rice weevil, Sitophilus oryzae (L.) in pop sorghum. M. Sc. (Agri.) Thesis, Univ. Agric. Sci., Dharwad.

Jilani, G. and Saxena. 1984. Use of botanicals for protection of stored food grain against insect pests - A review work done at grain storage research laboratory. P.A.R.C., Karachi, Pakistan, pp. 30-35.

Kalasagond, P. R., 1998, Management of beetle pests in stored wheat by non insecticidal approaches. M.Sc.(Agri.) Thesis, Uni. of Agric. Sci., Dharwad (India), 132pp.

Khan, M. I. and Borle, M. R. 1985. Efficacy of some grain protectant against the pulse beetle Callasobruchus chinensis L. infesting stored bengalgram (Cicer arietinum L.). PKV Res. J. 9: 53-55.

Kudachi, D.C., 2008, Management of lesser grain borer, Rhizopertha dominica Fab. and rice weevil, Sitophilus oryzae Linn. in stored sorghum. M. Sc. (Agri.) Thesis, Univ. Agric. Sci., Dharwad.

Lee, H.K., Park, C., Ahn,Y.J. 2002.Insecticidal activities of asarones identified in Acorus gramineusrhizome against Nilaparvata lugens (Homoptera: Delphacidae) and Plutella xylostella (Lepidoptera: Yponomeutoidae). Appl. Entomol. Zool., 37: 459-464.

Mahalakshmi, M. 2001. Seed conservation techniques against bruchid infestation in redgram. M.Sc (Ag.)Thesis, Acharya N.G.Ranga Agriculture University., Hyderabad.

Paneru, R. B., Duwadi, V. R. and Bhattarai,
M. R., 1993, Second year of testing locally available plant materials against S. oryzae in stored wheat. Pakhirbas Agric. Centre Work. Paper, Dhankuta, 88: 7-11.

Paneru, R. B., Patourel, G. N. J. and Kennedy, S. H., 1997. Toxicity of Acorus calamus rhizomes powder from Eastern Nepal to Sitophilus granarium (L.) and Sitophilus oryzae (L.) (Coleoptera, Curculianidae). J. Crop Prot., 16(8): 759-763.

Panse, V.G and Sukhatme, P.V. 1978. Statistical methods for Agricultural workers. ICAR New Delhi

Rajesh, G, Vipin, B, Prachi, L. 2017. The influence of some botanicals against rice weevil during storage in rabi sorghum. Journal of Researches in biosciences Agriculture and Technology. 5(1): 28-30.

Sandeep, D., Chandrashekhar, G.S., Ranganathswamy, M., Mallesh, S.B. Halesh Kumar, H.B. and Patibanda, A. K. 2013. Effect of botanicals on storability of sweet corn (Zea mays L. Saccharum) seeds International Journal of Plant Protection. 6(1):11-14.

Schmidt, G.H., Streloke, M. 1994. Effect of Acorus calamus (L.) (Araceae) oil and its main compound $\beta$-asarone on Prostephanus truncatus (Horn) (Coleoptera: Bostrichidae). J. Stored Prod. Res. 30: 227-235.

Shukla, A. C., Shahi, S. K. and Dikshit, A., 2002, Eucalyptus pauciflora - a potential source of sustainable, ecofriendly storage pesticide. Biotechnol. Microbes and Sustainable Utilization, 20: 93-107.

Singh. K., Agarwal, N. S. and Girish, G. K., 1974, Studies on quantitative loss in various high yielding varieties of maize due to Sitophilus oryzae (L.) (Coleoptera: Curculionidae). J. Sci. Technol. 12: 3-4. 
Subramanyam, B and Hagstrum, D.W. 1995. Resistant measurement and management. In: Subramanyam B, Hagstrum DW (Eds) Integrated management of insects in stored products. Marcel Dekker, New York, pp 331-397.

Sunilkumar, 2003. Survey of indigenous technologies and evaluation of botanicals against major storage pests. M. Sc. (Agri.) Thesis, Univ. Agril. Sci., Dharwad.

Tefera, T. 2012. Post-harvest losses in Africa maize in face of increasing food shortage. Food Sec. 4: 267-277

Uma Reddy, M. and Shobareddy. 1987. Effectiveness of selected plant material as protectants against insect infestation and nutrient components during storage of greengram (Vigna radiate). Bull.
Grain Tech. 25(1): 48-56

Vasanthraj David. B and Kumaraswamy, T. 1975. Elements of economic entomology 4th edition Madras. Popular Book Depot. pp. 279-280.

White, N.D.G., Leesch, J.G. 1995. Chemical control. In: Subramanyam B, Hagstrum DW (eds) Integrated management of insects in stored products. Marcel Dekker, New York, pp. 287-330.

Zunjare, R., Hossain, F., Thirunavkkarasu, N., Muthusamy, V., Jha, S. K., Kumar, P. and Gupta, H. S., 2014. Evaluation of specialty corn inbreeds for responses to stored grain weevil (Sitophilus oryzae L.) infestation. Indian Journal of Genetics and Plant Breeding. 74(4): 564-567.

\section{How to cite this article:}

Padmasri, A., C. Srinivas, K. Vijaya Lakshmi, T. Pradeep, K. Rameash, Ch. Anuradha and Anil, B. 2017. Management of Rice Weevil (Sitophilus oryzae L.) in Maize by Botanical Seed Treatments. Int.J.Curr.Microbiol.App.Sci. 6(12): 3543-3555. doi: https://doi.org/10.20546/ijcmas.2017.612.412 